\title{
CULMINANDO OTRO VOLUMEN DE MEDICINA CLÍNICA Y SOCIAL
}

\section{Iván BARRIOS ${ }^{1}$, Marcos ALMIRÓN² $^{2}$}

${ }^{1}$ Estudiante de Matemática Estadística, Facultad de Ciencias Exactas y Naturales, Universidad Nacional de Asunción, San Lorenzo - Paraguay. Editor Júnior, Revista Medicina Clínica y Social.

${ }^{2}$ Carrera de Kinesiología y Fisioterapia, Facultad de Ciencias Médicas, Universidad Nacional de Asunción, San Lorenzo - Paraguay. Editor Invitado, Revista Medicina Clínica y Social.

Cómo citar este artículo: Barrios I, Almirón M. Culminando otro volumen de Medicina Clínica y Social. Medicina Clínica y Social. 2018;2(3):108.

Nuevamente finalizamos un volumen de Medicina Clínica y Social, con mucho esfuerzo hemos continuado esta labor con el fin de dar a conocer las investigaciones realizadas en nuestro medio, queremos agradecer a todos los autores y revisores externos, ya que sin ellos no sería posible continuar con este emprendimiento.

Actualmente Medicina Clínica y Social se encuentra indizada en varias bases de datos, y estamos en trámites para llegar a muchas más con el siguiente volumen. En este volumen que estamos cerrando publicamos once artículos originales, tres lecciones de medicina, tres cartas al editor, un reporte de caso y un artículo especial.

Debemos siempre recordar que la única forma de cerrar un ciclo de investigación, es finalmente dando a conocer nuestros resultados a la comunidad científica, la única manera de hacer eso es publicando nuestra investigación en una revista con revisión por pares. Dado esto, la revista siempre está abierta a que estudiantes de diferentes disciplinas ligadas a la medicina envíen sus artículos para revisión, de esta manera queremos contribuir a un acercamiento temprano al campo científico.

\section{CONFLICTOS DE INTERÉS Y FUENTE DE FINANCIACIÓN}

El autor declara no poseer conflictos de interés. Fuente de financiación: ninguna.

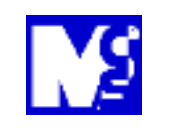




\section{FINISHING ANOTHER VOLUME OF MEDICINA CLÍNICA Y SOCIAL}

\section{Iván BARRIOS ${ }^{1}$, Marcos ALMIRÓN²}

${ }^{1}$ Statistical Mathematic student, Exact and Natural Sciences School, National University of Asunción, San Lorenzo - Paraguay. Junior Editor, Medicina Clínica y Social.

${ }^{2}$ Kinesiology and Physiotherapy, Faculty of Medical Sciences, National University of Asunción, San Lorenzo - Paraguay. Guest Editor, Medicina Clínica y Social.

How to cite this article: Barrios I, Almirón M. Culminando otro volumen de Medicina Clínica y Social. Medicina Clínica y Social. 2018;2(3):108.

Once again we finished a volume of Clinical and Social Medicine, with a lot of effort we have continued this work in order to make known the research done in our environment, we want to thank all the authors and external reviewers, because without them it would be possible to continue with this endeavor.

Currently Clinical and Social Medicine is indexed in several databases, and we are in the process of reaching many more with the following volume. In this volume that we are closing we publish eleven original articles, three medical lessons, three letters to the editor, a case report and a special article.

We must always remember that the only way to close a research cycle is by finally making our results known to the scientific community, the only way to do that is by publishing our research in a peer-reviewed journal. Given this, the journal is always open to students from different disciplines linked to medicine to send their articles for review, in this way we want to contribute to an early approach to the scientific field.

\section{CONFLICTS OF INTEREST AND FUNDING}

Conflicts of interest: none. Funding source: none.

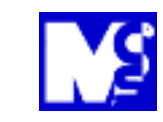

